\title{
A Groundwater-Flow Model for the Treasure Valley and Surrounding Area, Southwestern Idaho
}

\author{
The U.S. Geological Survey (USGS), in partnership with the Idaho Department of Water
} Resources (IDWR) and Idaho Water Resource Board (IWRB), will construct a numerical groundwater-flow model of the Treasure Valley and surrounding area. Resource managers will use the model to simulate potential anthropogenic and climatic effects on groundwater for water-supply planning and management. As part of model construction, the hydrogeologic understanding of the aquifer system will be updated with information collected during the last two decades, as well as new data collected for the study.

\section{The Treasure Valley}

The Treasure Valley is "the agricultural area that stretches west from Boise into Oregon" (U.S. Board on Geographic Names, 2016), although it is commonly referred to as the lower Boise River Basin. The valley contains the three largest and sixth largest cities in Idaho-Boise, Meridian, Nampa, and Caldwell, respectively (fig. 1). The 2016 population of the Treasure Valley was about 630,000 , representing about 37 percent of the total population of Idaho (SPF Water Engineering, 2016; U.S. Census Bureau, 2017). Except for the 30 percent of Boise's municipal supply taken from the Boise River (Suez North America, 2017), groundwater withdrawals provide all domestic and municipal water in the valley.

SPF Water Engineering (2016) estimated that the population of the Treasure Valley will increase to about 1.6 million by 2065 , resulting in a corresponding increase in domestic, commercial, municipal, and industrial water demand. To address this anticipated demand for water, the Idaho Senate passed Concurrent Resolution 137 , which includes a request to "develop a ground water model, with all necessary measurement networks" for the Treasure Valley (Idaho Senate Resources and Environment Committee, 2016, p. 2).

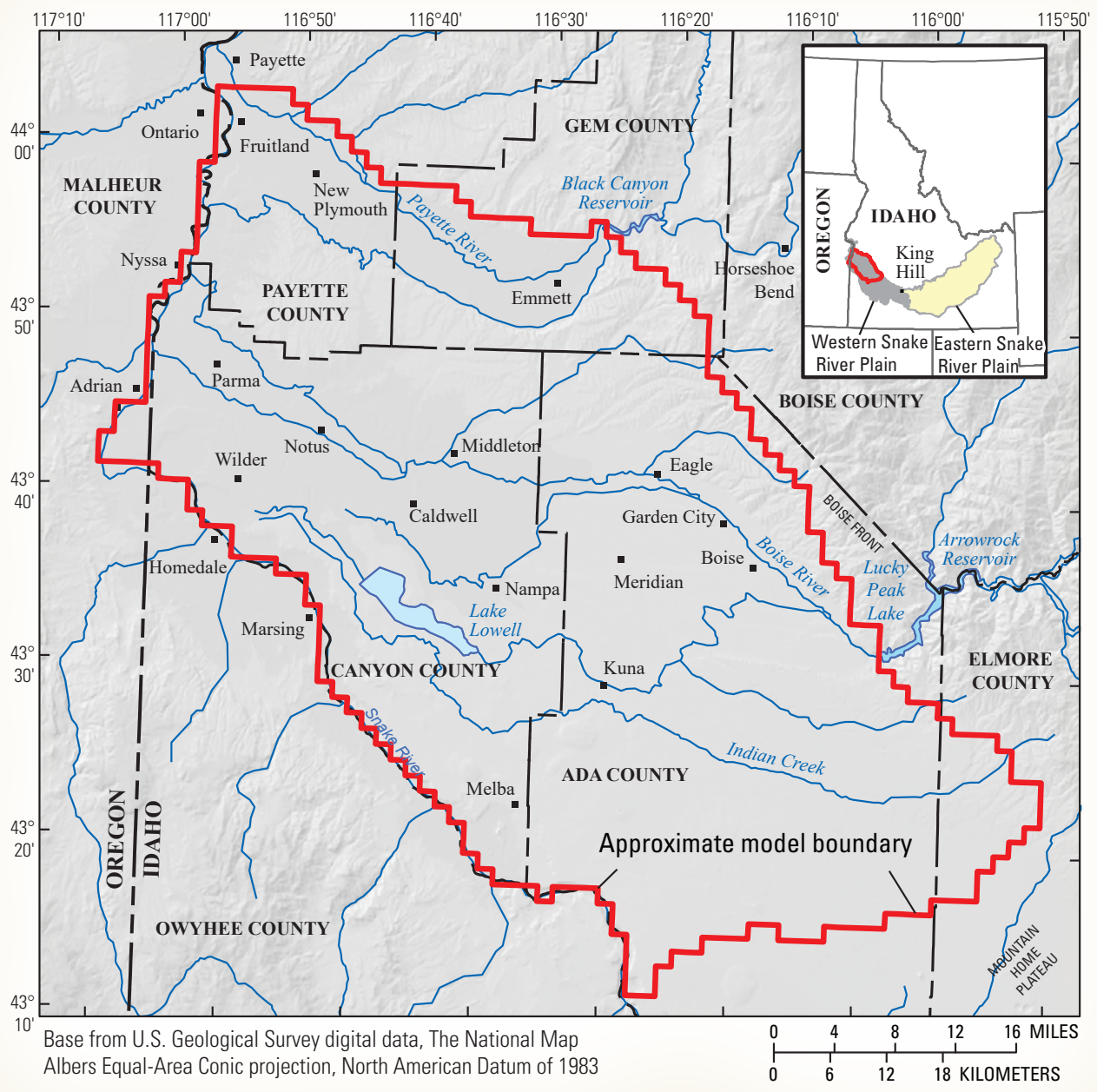

Figure 1. Locations of communities, the boundary of approximate model extent, and other features, Treasure Valley, southwestern Idaho. 


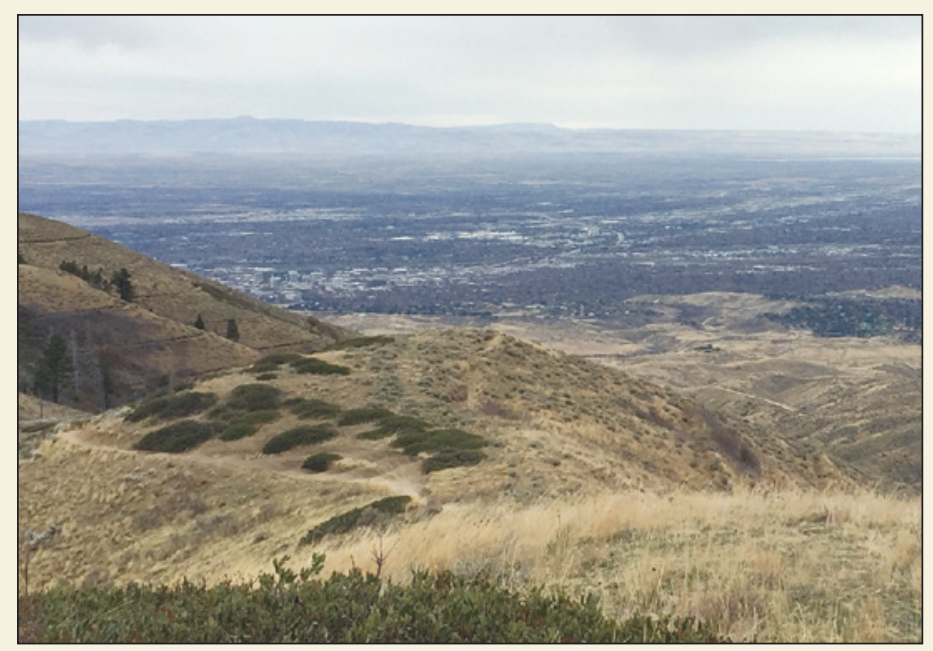

View of Treasure Valley looking southwest from the Boise Front, Idaho. Photograph by James R. Bartolino, November 19, 2016.

The hydrologic boundaries of the Treasure Valley aquifer system are generally considered to be the Snake River to the south and west, the Mountain Home plateau to the east, and the uplands that divide the Boise and Payette River Basins to the north (fig. 1). The current study will extend the northern model boundary to the Payette River valley and the cities of Emmett, New Plymouth, and Fruitland because the surfacewater divide separating the Boise and Payette River Basins is not a continuous barrier to groundwater flow. This area is also the site of current development and proposed large-scale residential development.

\section{Hydrology of the Treasure Valley}

The Treasure Valley lies within the Snake River Plain, "an arcuate topographic and structural depression that extends across southern Idaho. Geology and hydrology of [the] eastern and western parts of the Snake River Plain are distinctly different; the west is predominantly sedimentary rocks, and the east is predominantly volcanic rocks" (Newton, 1991, p. G2). Prolific and unconnected aquifer systems underlie the two halves of the Snake River Plain; the eastern and western halves are separated by a hydrologic boundary in the area near King Hill. The western Snake River Plain was formed after volcanic activity led to faulting that caused the plain to subside relative to the surrounding mountains. The resulting basin filled with river and lake sediments that are interbedded with basalt in places; these deposits form the aquifer system underlying the Treasure Valley and immediate area. Geologic activity and glacial cycles during deposition created complexity in these deposits; thus, aquifer characteristics can change abruptly with small changes in depth or location. This complexity partitions the overall aquifer system into a number of interconnected aquifers with varying water levels, chemistry, and productivity. After basinfill deposition ended, subsequent erosion caused by the Snake, Boise, and Payette Rivers formed the current landscape of the Treasure Valley and surrounding area (Wood and Clemens, 2002).

Groundwater occurs under unconfined and confined conditions; some wells completed in the confined aquifers flow in areas where the potentiometric head is above land surface. In general, depth to groundwater varies from land surface or above to depths of more than $800 \mathrm{ft}$ below land surface. The aquifer system can broadly be conceptualized as having three parts - a shallow water-table aquifer; a complex deep, underlying aquifer under confined conditions; and a lowermost confined geothermal aquifer. Groundwater flow in the shallow aquifer is generally from topographic highs to rivers and drains.

The main, natural surface-water features of the Treasure Valley are the Snake River to the south, the Boise River in the central valley, and the Payette River to the north. The availability of water for agriculture diverted from the Boise and Payette Rivers was the primary reason for settlement in the area; a complex network of reservoirs, irrigation canals, laterals, ditches, and drains was constructed to support this irrigation (Stacy, 1993).

Prior to the late 1940s, groundwater use was limited to very shallow wells or to wells that flowed under artesian pressure. In 1891, artesian wells near the old State Penitentiary began supplying geothermal water for heating; by 1897 , artesian wells in Hulls Gulch provided the municipal supply for Boise (Lindgren, 1898; Wood and Burnham, 1983). Groundwater pumping increased steadily after the development of pumps capable of efficiently lifting water from greater depths in the late-1940s.

Authors of earlier water budgets for the area have identified the largest components of recharge to the aquifer system as seepage from the canal system (including Lake Lowell) and infiltration of applied irrigation water. The largest components of discharge from the aquifer system are seepage to rivers and drains, followed by pumping from wells (Newton, 1991; Petrich and Urban, 2004). Although these water budgets were comparable regarding the relative magnitudes of their components, they can be improved by collecting new, additional data (such as groundwater discharge to drains) and by applying new interpretive techniques (such as the determination of evapotranspiration rates using satellite imagery). In addition, previous efforts did not evaluate year-to-year and seasonal variations in the groundwater budget. In contrast, the present study involves developing a monthly water budget for a 30 -year timeframe (1986-2015).

\section{Groundwater Modeling -A Tool for Understanding and Managing the Resource}

In the most general terms, a model is a simplified representation of the appearance or operation of a real object or system. Groundwater-flow models attempt to reproduce, or simulate, the processes of a real aquifer system by solving a series of mathematical equations. Groundwater-flow models are usually constructed by representing the geology of the groundwater system as a series of rectangular, three-dimensional blocks or model cells surrounded by a hydrologic boundary (figs. 2 and 3).

A numerical computer model is a program containing equations that represent groundwater flow between the model cells. As the equations are solved, the program accounts for the flow of water through the model domain and for each cell; a groundwater-flow model calculates the volume of water flowing horizontally and vertically between the cells, and any changes in the volume of water stored in each cell. Groundwater-flow models often represent the best available tool for management decisions (Alley and others, 1999). 


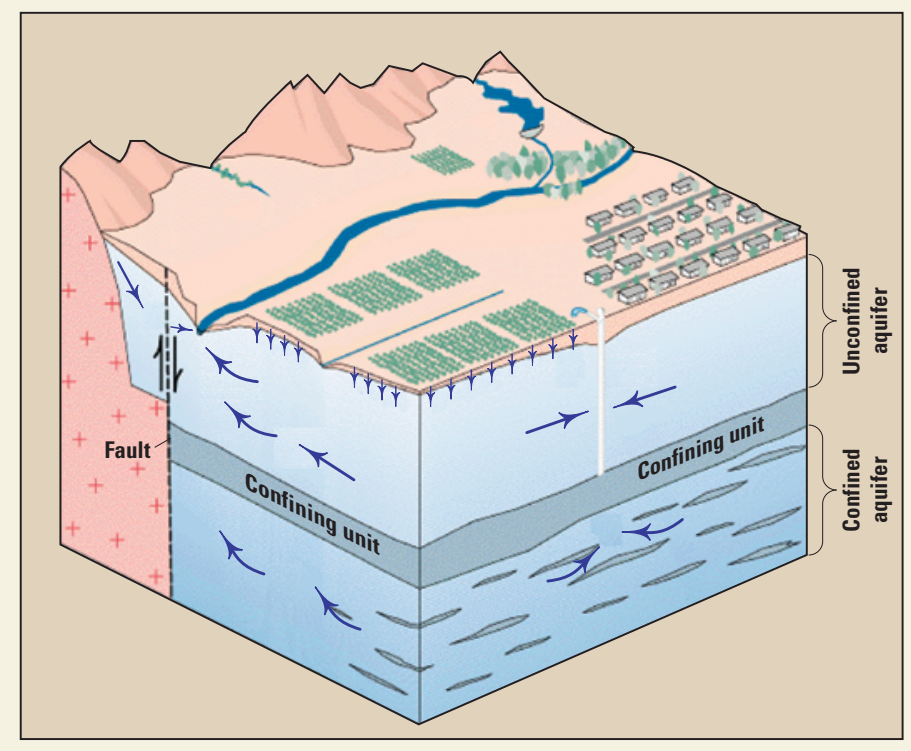

Figure 2. Block diagram of part of a hypothetical basin-fill groundwater system. The blue arrows show the direction of groundwater flow. Among the features shown are an unconfined aquifer overlying a confining unit and confined aquifer, a gaining stream, infiltration from irrigated agriculture, and mountain-front recharge. Modified from Leake (1997) and Reilly and McAda (2002).

One of the keys to a successful groundwater-flow model that produces useful forecasts is the apt representation of important aspects of the physical system. The selection of these aspects depends, in part, on the objectives of the modeling project. These modeling objectives also influence the extent and depth of the modeled area, the size and shape of the model cells and layers, the methods used to represent the boundary conditions of the system, and the use of any specialized techniques or equations to address specific flow conditions or processes.

Eight groundwater-flow models have been published that include all or part of the Treasure Valley (Cosgrove, 2010; Johnson, 2013). These models were constructed with varying objectives, detail, and model extent. The USGS-IDWR Treasure Valley groundwater-flow model will incorporate new data and interpretations that were unavailable in previous efforts. As a transient model, it will be designed to advance the basic understanding of the aquifer system and, ultimately, to consider how changes in water use, recharge, or discharge may affect the groundwater system and its interaction with surface water. Additionally, by attempting to mathematically represent the groundwater-flow system, the model can be used to analyze the understanding of system components and which have the most effect on model forecasts. This analysis can then be used to guide the collection of additional data that will most improve the understanding of the Treasure Valley aquifer system.

\section{Collaborative USGS-IDWR Groundwater-Flow Model Project}

The USGS established the first streamgage in the Treasure Valley in 1895 , the same year that the Office of the State Engineer (a precursor agency to the IDWR) was established. Since then, the USGS and the State of Idaho have cooperated with each other, numerous local governments, and other entities to understand the water resources of the Treasure Valley.

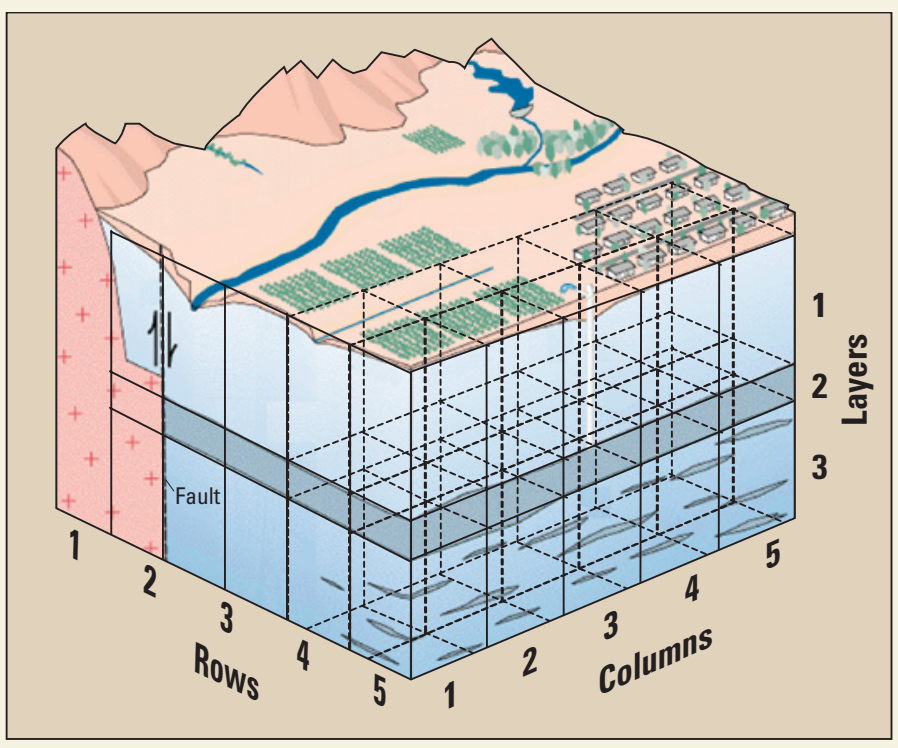

Figure 3. Block diagram of part of a hypothetical basin-fill groundwater system with some model cells shown superimposed. The model cells cover the entire groundwater system being simulated. Modified from Leake (1997) and Reilly and McAda (2002).

The USGS, in collaboration with the IDWR, will incorporate an improved understanding of the Treasure Valley aquifer system into a groundwater-flow model that will serve as a tool for water-rights administration and water-resource management and planning. The 5-year study is scheduled to begin in late 2016 and conclude in 2021. Additional data collection for the study, including streamflow measurements on drains, started in October 2016.

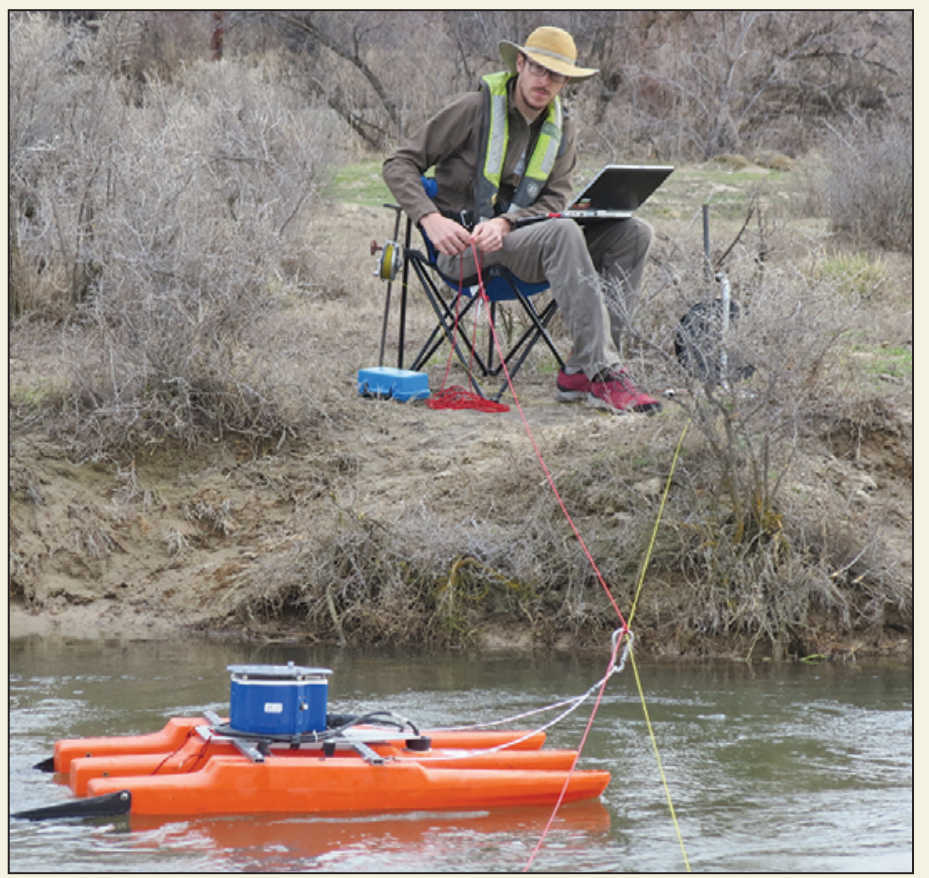

U.S. Geological Survey hydrographer making a stream-discharge measurement in Sand Run Gulch near Parma, Idaho. Photograph by James R. Bartolino, March 14, 2017. 
A transient numerical groundwater-flow model will be constructed using a version of the public domain computer program, MODFLOW, to simulate potential human-caused and natural effects on groundwater and surface-water resources. The USGS is scheduled to publish an initial report in 2019 describing improvements in the hydrogeologic framework, conceptual water budget, and conceptual model. At the conclusion of the study in 2021, the USGS will publish the documented model and a final report to describe the groundwater-flow model construction and limitations, as well as results from one or two simulations that represent a range of potential anthropogenic activities and hydrologic conditions (formulated in consultation with stakeholders). The documented model will be published by the USGS and made publically available through USGS and IDWR websites.

A technical advisory committee (TAC) will be formed to provide transparency in model development and to facilitate stakeholder input. The IDWR will seek representation on the TAC from municipalities, irrigation entities, water-user groups, and other Treasure Valley stakeholders. This TAC will be similar to committees established for two previous USGS-IDWR collaborative groundwater-flow model development studies: the Wood River Valley Groundwater Flow Model Project (Fisher and others, 2016), and the Spokane Valley-Rathdrum Prairie Hydrologic Project (Hsieh and others, 2007).

\section{References Cited}

Alley, W.M., Reilly, T.E., and Franke, O.L., 1999, Sustainability of ground-water resources: U.S. Geological Survey Circular 1186, 79 p. [Also available at http://pubs.er.usgs.gov/publication/cir1186.]

Cosgrove, D.M., 2010, Evaluation of ground water models in the Treasure Valley, Idaho Area: Idaho Falls, Western Water Consulting, Inc., 134 p. [Also available at http://www.idwr.idaho. gov/Browse/WaterInfo/EADA/contractor_findings/.]

Fisher, J.C., Bartolino, J.R., Wylie, A.H., Sukow, Jennifer, and McVay, Michael, 2016, Groundwater-flow model for the Wood River Valley aquifer system, South-Central Idaho: U.S. Geological Survey Scientific Investigations Report 2016-5080, 71 p., 6 appendices. [Also available at http://dx.doi.org/10.3133/ sir20165080.]

Hsieh, P.A., Barber, M.E., Contor, B.A., Hossain, M.A., Johnson, G.S., Jones, J.L., and Wylie, A.H., 2007, Ground-water flow model for the Spokane Valley-Rathdrum Prairie Aquifer, Spokane County, Washington, and Bonner and Kootenai Counties, Idaho: U.S. Geological Survey Scientific Investigations Report 2007-5044, 79 p. [Also available at http://pubs.usgs.gov/ $\operatorname{sir} / 2007 / 5044 /$.

Idaho Senate Resources and Environment Committee, 2016, Senate Concurrent Resolution 137: Legislature of the State of Idaho, 63rd, 2nd session, 2 p. [Also available at https://legislature.idaho. gov/legislation/2016/SCR137Bookmark.htm.]

Johnson, Jennifer, 2013, Development of a transient groundwater model of the Treasure Valley aquifer, Idaho: Boise, Bureau of Reclamation, July 2013, 43 p.

Leake, S.A., 1997, Modeling ground-water flow with MODFLOW and related programs: U.S. Geological Survey Fact Sheet 121-97, 4 p. [Also available at http://pubs.usgs.gov/fs/FS-121-97/.]

Lindgren, Waldemar, 1898, Boise folio, Idaho: U.S. Geological Survey Folios of the Geologic Atlas 45, 7 p., 4 pl. [Also available at https://pubs.er.usgs.gov/publication/gf45.]
Newton, G.D., 1991, Geohydrology of the regional aquifer system, western Snake River Plain, southwestern Idaho: U.S. Geological Survey Professional Paper 1408-G, 52 p., 1 plate in pocket. [Also available at http://ngmdb.usgs.gov/Prodesc/proddesc_4859.htm.

Petrich, C.R., and Urban, S., 2004, Characterization of ground water flow in the lower Boise River basin: Moscow, University of Idaho Water Resources Research Institute, Research Report IWRRI2004-01, 148 p. [Also available at http://www.idwr.idaho.gov/files/ projects/treasure-valley/TVHP-Characterization.pdf.]

Reilly, T.E., and McAda, D.P., 2002, Ground-water-flow models and how they are used to study the basin, in Bartolino, J.R., and Cole, J.C., 2002, Ground-water resources of the middle Rio Grande Basin, New Mexico: U.S. Geological Survey Circular 1222, p. 102-103. [Also available at http://pubs.er.usgs.gov/ usgspubs/ cir/cir1222.]

SPF Water Engineering, 2016, Treasure Valley DCMI waterdemand projections (2015-2065): Boise, SPF Water Engineering, 131 p., 3 appendices. [Also available at http://www.idwr.idaho. gov/files/publications/20160808-OFR-Treasure-Valley-WaterDemand-(2015-2065).pdf.]

Stacy, S.M., 1993, When the river rises-Flood control on the Boise River 1943-1985: Boulder, University of Colorado Program on Environment and Behavior Special Publication 27, 187 p.

Suez North America, 2017, About your water: Suez North America website, accessed February 13, 2017, at http://www.mysuezwater. com/idaho/water-in-my-area/about-my-water.

U.S. Board on Geographic Names, 2016, Feature detail report for Canyon County: U.S. Geological Survey website, accessed July 20, 2016, at http://geonames.usgs.gov/apex/f?p=gnispq:3:::NO::P3 FID: 399406.

U.S. Census Bureau, 2017, QuickFacts, Idaho: U.S. Census Bureau database, accessed March 7, 2017, at https://www.census.gov/ quickfacts/table/PST045215/16.

Wood, S.H., and Burnham, W.L., 1983, Boise, Idaho geothermal system: Geothermal Resources Council, Transactions, v. 7, p. 215-223.

Wood, S.H., and Clemens, D.M., 2002, Geologic and tectonic history of the western Snake River Plain, Oregon and Idaho, in Bonnichsen, B., White, C.M., and McCurry, M., eds., 2004, Tectonic and magmatic evolution of the Snake River Plain Volcanic Province: Moscow, Idaho: Geological Survey Bulletin 30, p. 69-103. [Also available at http://www.idahogeology.org/ Products/reverselook.asp?switch=title\&value=Tectonic_and Magmatic_Evolution_of_the_Snake_River_Plain_Volcanic_ Province.]

\section{Authors:}

James R. Bartolino, U.S. Geological Survey

Sean Vincent, Idaho Department of Water Resources

For more information contact:

Director, Idaho Water Science Center

U.S. Geological Survey

F.H. Newell Federal Building, 230 Collins Road, Boise, ID 83702

Publishing support provided by the U.S. Geological Survey Science Publishing Network

Tacoma Publishing Service Center

ISSN 2327-6916 (print)

ISSN 2327-6932 (online 